\title{
CONDITIONS OF FORMATION OF EUGLOBULIN-LIKE PRECIPITATES FROM SERUM PROTEINS AND CHONDROITIN SULFATE ${ }^{1}$
}

\author{
BY JACQUES BADIN ${ }^{2}$ AND MAXWELL SCHUBERT \\ (From the Departments of Chemistry and Medicine, and the Study Group on Rheumatic \\ Diseases, New York University College of Medicine, New York, N. Y.)
}

(Submitted for publication March 10, 1955; accepted March 30, 1955)

The present work constitutes a study of the conditions under which chondroitin sulfate and serum proteins can produce insoluble complexes which behave like euglobulins. Euglobulins are characterized by insolubility in distilled water, solubility in dilute salt solutions and reprecipitability by dialysis of such salt solutions against distilled water.

When potassium chondroitin sulfate is added to normal human serum, no apparent change occurs, but on dialysis a larger amount of euglobulin precipitates. Table I shows an example. To 6 ml. samples of human serum, diluted with an equal volume of water, were added different amounts of potassium chondroitin sulfate (1). Samples were dialyzed 48 hours against a citratephosphate buffer, $\mathrm{M} / 150, \mathrm{pH} 5.5$, according to the method of Sandor, Sabetay, and Vargues (2). After dialysis, euglobulins were centrifuged down, washed with buffer and the amount of proteins precipitated determined using the biuret reaction (3).

As expected from the foregoing data, potassium chondroitin sulfate added to serum that has been previously dialyzed and centrifuged causes a further precipitate which appears as extra euglobulin. The effect of variation in salt concentration, in concentration of chondroitin sulfate and protein, and in $\mathrm{pH}$, in this reaction have been studied.

\section{METHODS}

The protein solution used to study precipitation with chondroitin sulfate was human serum freed of euglobulin

1 This investigation was supported (in part) by research grant A-28(C) from the National Institute of Arthritis and Metabolic Diseases, United States Public Health Service, and (in part) by the Masonic Foundation for Medical Research and Human Welfare, and (in part) by the New York Chapter, The Arthritis and Rheumatism Foundation.

2 Smith-Mundt, Fulbright Fellow, Present address: Medical Faculty, University of Paris, Paris, France. by dilution with one volume of water and dialysis for 3 to 4 days against a citrate-phosphate buffer, $.01 \mathrm{M}$, $\mathrm{pH} 4.5$ to 5.5. Euglobulins were removed by centrifugation and the supernatant was diluted with buffer until the concentration of total proteins, as determined with the biuret reaction of Jayle, Boussier, and Badin (3), was $10 \mathrm{mg}$. per $\mathrm{ml}$. For some purposes (as experiment c) a similar euglobulin-free diluted serum was made using distilled water throughout instead of buffer. These preparations are called "diluted dialyzed serum" in buffer and in water. Protein precipitated from these preparations by chondroitin sulfate under various conditions was determined by the biuret reaction on the water washed precipitates in the following experiments.

\section{RESULTS}

(a) To a series of tubes, each containing $5 \mathrm{ml}$. of the diluted dialyzed serum in buffer $\mathrm{pH} 5.1$, were added increasing amounts of $\mathrm{NaCl}$ and the volumes were made to $10 \mathrm{ml}$. with water. The concentration of salt varied from $0.01 \mathrm{M}$ to $0.3 \mathrm{M}$. Potassium chondroitin sulfate $(2 \mathrm{mg}$. in $1 \mathrm{ml}$.) was added to each tube and the precipitates were centrifuged after standing 2 to 4 hours at room temperature. Figure 1 shows how increasing the concentration of $\mathrm{NaCl}$ decreases the protein precipitated.

(b) When chondroitin sulfate is added in increasing amounts to the diluted dialyzed serum in water, the protein precipitated increases to a peak and then diminishes as shown in Figure 2, curve A. At concentrations of chondroitin sul-

TABLE I

A mounts of protein precipitable on dialysis from serum containing added chondroitin sulfate

\begin{tabular}{ccc}
\hline $\begin{array}{c}\text { Potassium } \\
\text { chondroitin } \\
\text { sulfate } \\
\text { added }\end{array}$ & $\begin{array}{c}\text { Precipitated } \\
\text { euglobulin }\end{array}$ & $\begin{array}{c}\text { Increase in } \\
\text { euglobulin due } \\
\text { to chondroitin } \\
\text { sulfate added }\end{array}$ \\
\hline$m g$. & $m g$. & $m g$. \\
0 & 19.2 & 0 \\
.5 & 23.0 & 3.8 \\
1.0 & 26.2 & 7.0 \\
1.5 & 28.8 & 9.6
\end{tabular}




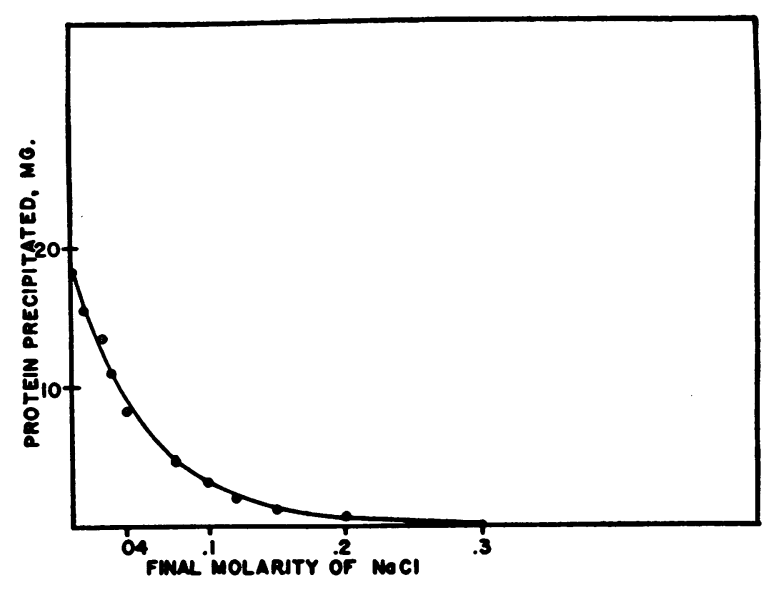

Fig. 1. Protein Precipitated with Chondroitin Sulfate and Diluted Dialyzed Serum: Effect of Sodium Chloride Concentration

Serum proteins (100 mg.) and potassium chondroitin sulfate $(2 \mathrm{mg}$ ) in citrate-phosphate buffer $(10 \mathrm{ml}$.), .01 $\mathrm{M} \mathrm{Na} \mathrm{HPO}_{4}, \mathrm{pH}$ 5.1.

fate over three times that causing the peak precipitation of protein, chondroitin sulfate does not precipitate any protein. At the optimal concentration, the ratio between the weight of precipi- tated protein and added polysaccharide is between 5 and 7.

(c) To a series of tubes, each containing $5 \mathrm{ml}$. diluted dialyzed serum in water and $0.5 \mathrm{ml}$. $\mathrm{Na}_{2} \mathrm{HPO}_{4}$ solution $0.2 \mathrm{M}$, increasing amounts of citric acid solution $0.1 \mathrm{M}$ were added ( 0.1 to 1.5 $\mathrm{ml}$.) to give a range of $\mathrm{pH}$ from 7.5 to 4.0 . If in some tubes any precipitate appeared it was removed by centrifugation. After standing an hour, a constant amount of potassium chondroitin sulfate ( $1 \mathrm{mg}$.) was added to all tubes and volumes were made to $10 \mathrm{ml}$. Figure 3 shows how the amount of protein precipitated by the polysaccharide depends on the $\mathrm{pH}$ (curve A). Figure 2 shows how markedly the shape of the curve relating the amount of protein precipitated and the amount of potassium chondroitin sulfate added depends on $\mathrm{pH}$. At $\mathrm{pH} 5.5$ (Figure 2, curve $\mathrm{B}$ ) the curve reaches a plateau, at $\mathrm{pH} 4.6$ (Figure 2, curve $\mathrm{C}$ ) there is neither a peak nor a plateau.

(d) Comparison at $\mathrm{pH} 4.6$ of the precipitation curves of the globulin and the albumin fractions (separated with 55 per cent ammonium sulfate) on addition of increasing amounts of chondroitin sulfate shows that albumin produces a linear

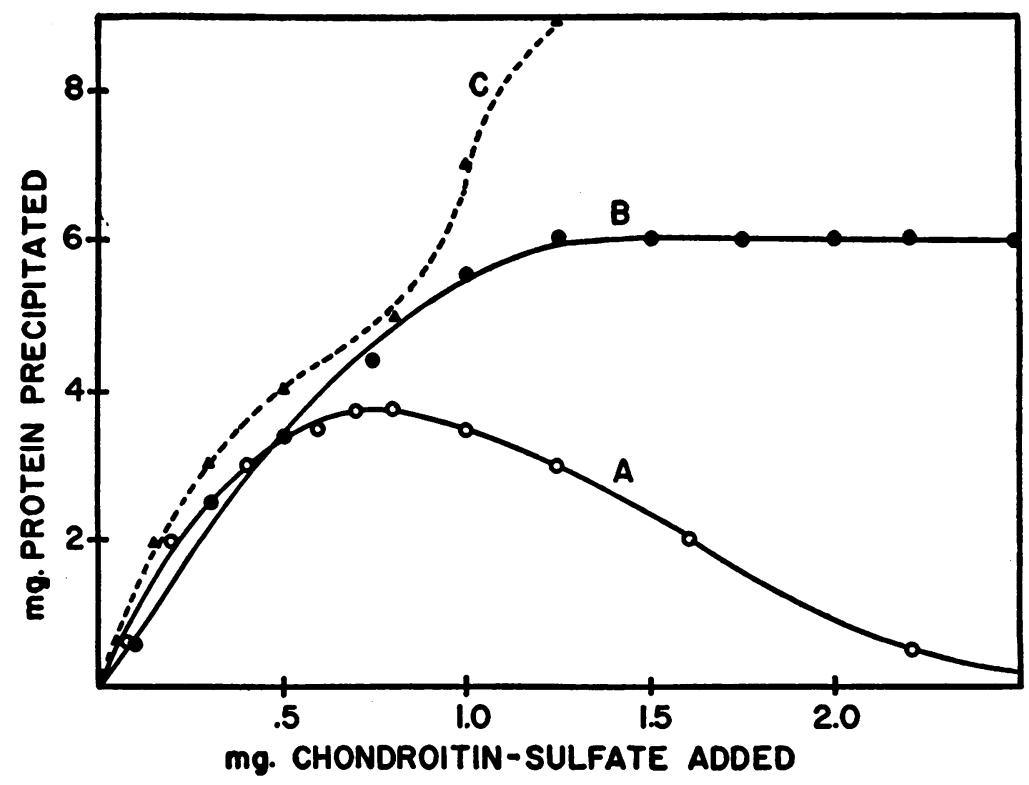

Fig. 2. Protein Precipitated from Diluted Dialyzed Serum (50 Mg. Protein in 10 Ml.) with Increasing Amounts of Potassium ChonDROITIN Sulfate

A, no buffer; $\mathrm{B}$, citrate-phosphate buffer, .01 $\mathrm{M} \mathrm{Na} \mathrm{Na}_{2} \mathrm{HPO}_{4}, \mathrm{pH} 5.5 ; \mathrm{C}$, citrate-phosphate buffer, .01 M Na $\mathrm{HPO}_{4}, \mathrm{pH} 4.6$. 


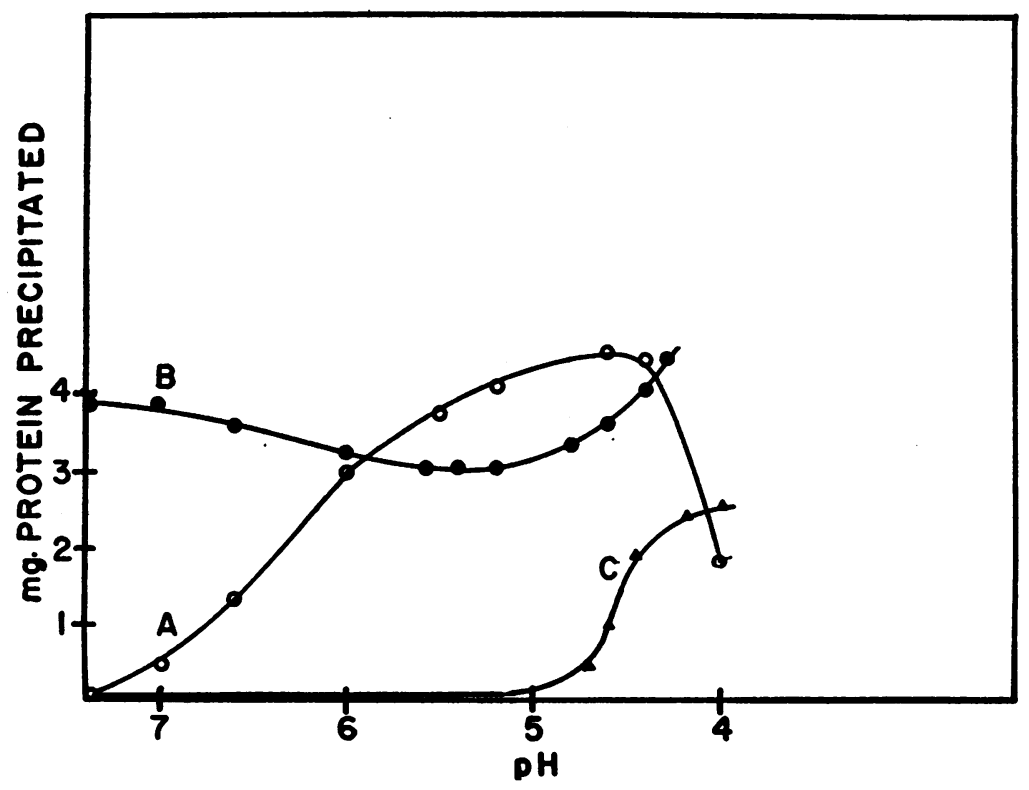

Fig. 3. Protein Precipitated with Chondroitin Sulfate

Each solution contained protein (50 mg.), potassium chondroitin sulfate (.5 mg.) and $.01 \mathrm{M} \mathrm{Na} \mathrm{HPO}_{4}(10 \mathrm{ml}$.) to which were added increasing amounts of citric acid to vary the $\mathrm{pH}$. A, proteins of dialyzed serum; $\mathrm{B}$, as $\mathrm{A}$, but containing in addition $15 \mathrm{mg}$. lysozyme and clearing any turbidity produced by centrifugation before adding the chondroitin sulfate; $\mathrm{C}$, serum albumin, commercial.

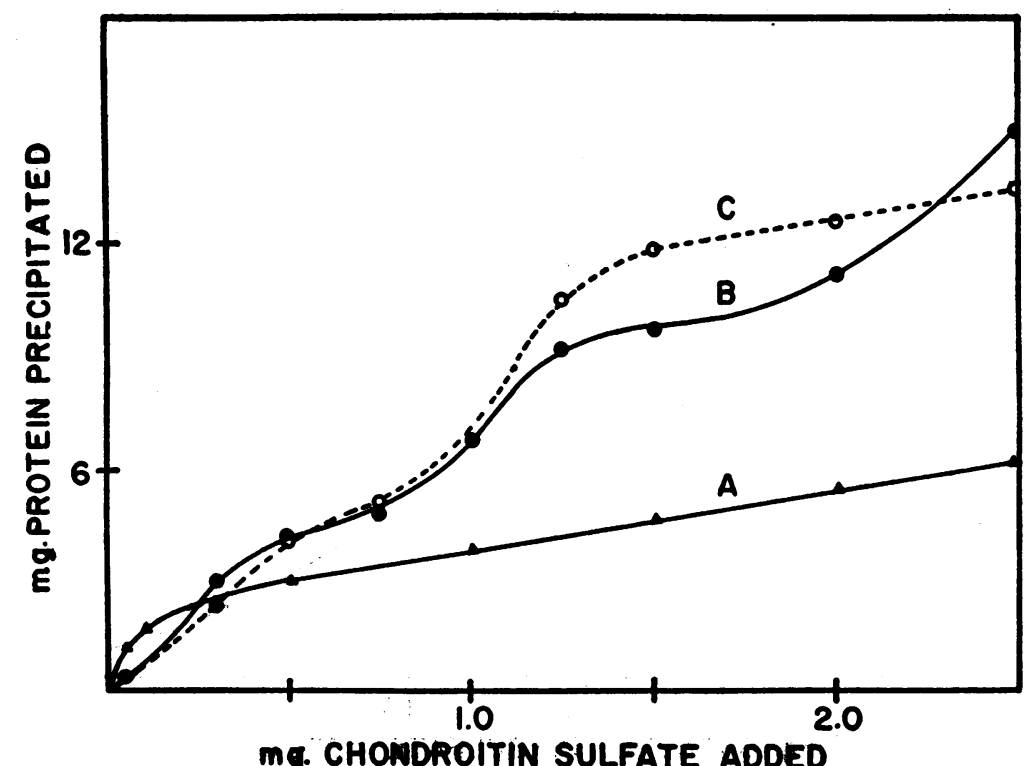

Fig. 4. Protein Precipitated with Increasing Amounts of ChonDROITIN SULFATE

Each solution contained protein ( $50 \mathrm{mg}$ ) in citrate-phosphate buffer (10 ml.) $.01 \mathrm{M} \mathrm{Na} \mathrm{HPO}_{4}, \mathrm{pH}$ 4.6. A, serum albumin; $\mathrm{B}$, dialyzed serum; C, serum pseudo globulin. 


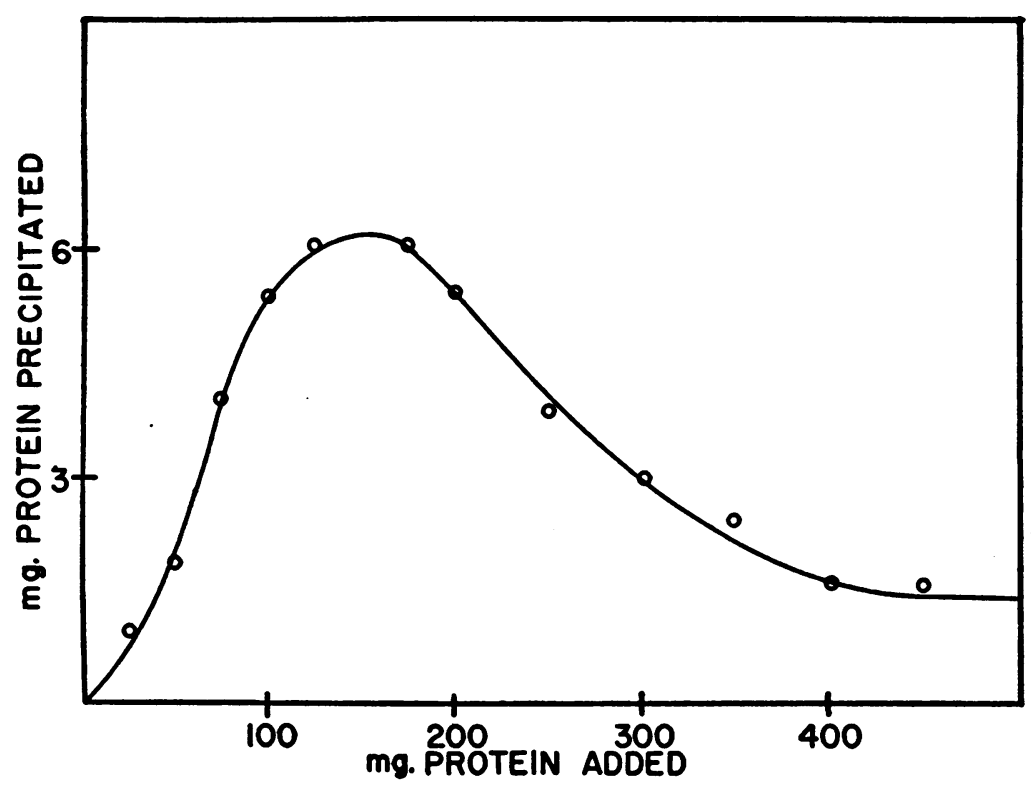

Fig. 5. Protein Precipitated with Chondroitin Sulfate

Effect of increasing amounts of dialyzed serum proteins added to potassium chondroitin sulfate $(2 \mathrm{mg}$.) in citrate-phosphate buffer $(10 \mathrm{ml} .) .01$, $\mathrm{M} \mathrm{Na} \mathrm{HPO}_{4}, \mathrm{pH}$ 4.6.

curve (Figure 4, curve A) quite different from that produced by the globulins (Figure 4, curve C). This latter curve has two shoulders, probably related to the precipitation of different groups of proteins. Moreover, the amount of precipitate formed is smaller for the albumin than for the globulin fraction. At $\mathrm{pH} 4.6$ albumin is readily precipitable by $\mathrm{K}$ chondroitin sulfate, but at this $\mathrm{pH}$ the precipitation curve of the whole serum, Figure 4, curve B, does not lie between the curves of the two fractions, but closely follows the globulin fraction curve, at least in its first part. Hence, it seems likely that the precipitation of serum proteins by chondroitin sulfate is mainly a precipitation of globulins.

(e) As shown in Figure 5, the precipitation of the protein-polysaccharide complex increases with the protein concentration to a maximum and then decreases rapidly. No precipitation occurs when the amount of protein reaches 3 or 4 times its concentration at the optimum.

Proteins with a very high isoelectric point produce precipitates with chondroitin sulfate at more alkaline reaction than any serum proteins. For instance, lysozyme ( $\mathrm{pKi} 10.5$ to 11 according to Alderton, Ward, and Fevold [4]) added to a dialyzed serum diluted with a weak buffer gives a completely different precipitation curve as a function of the $\mathrm{pH}$. As shown in Figure 3, curve $\mathrm{B}$, precipitation remains practically at a plateau between $\mathrm{pH} 8$ and 5 as if lysozyme bound polysaccharide down to a $\mathrm{pH}$ acid enough so the serum proteins could compete successfully with lysozyme.

\section{DISCUSSION}

The nature of the complexes between serum proteins and chondroitin sulfate is not completely clear. Meyer, Palmer, and Smyth (5) gave evidence of salt formation between cationic groups of the proteins and anionic groups of the polysaccharides. A precipitation curve of lysozyme in water with no buffer added, similar to curve $A$ of Figure 2, shows a peak when the ratio of the weight of polysaccharide to the weight of protein is .25. Chemical determination, by the tryptophan method (6), of the polysaccharide in the precipitate with lysozyme has given a polysaccharide to protein ratio of .27. These figures are close to the weight of anionic polysaccharide equivalent to the cationic groups per gram of lysozyme (according to Fromageot [7]).

The redissolution of precipitated protein at higher concentrations of chondroitin sulfate may 
be due to the action of the polysaccharide as a salt, similar to that shown in Figure 1. At high concentration of polysaccharide solutions containing protein are opalescent but remain perfectly stable. The appearance and redissolution of precipitated protein-polysaccharide complex with increasing amounts of chondroitin sulfate (Figure 2) may be related to the appearance and disappearance of metachromatic color in solutions of toluidine blue 0 with increasing amounts of chondroitin sulfate (8). Metachromasy of toluidine blue 0 induced by chondroitin sulfate also disappears on addition of salt as does the proteinpolysaccharide precipitate (Figure 1).

As pointed out by Meyer, Palmer, and Smyth, the formation of precipitates of proteins with chondroitin sulfate depends on their $\mathrm{pKi}$ and the $\mathrm{pH}$ of the solution. Albumin which has a $\mathrm{pKi}$ lower than that of globulins starts to precipitate with the polysaccharide at $\mathrm{pH} 4.9$, while globulins begin to precipitate at $\mathrm{pH}$ 6.9. Lysozyme which has a pKi much higher than that of globulins, precipitates with chondroitin sulfate even at $\mathrm{pH}$ higher than 8 . The results of this study provide an experimental basis defining the conditions under which chondroitin sulfate might take part in the formation of fibrinoid, sclerotic, hyaline, and amyloid material as suggested by Altschuler and Angevine (9).

\section{SUMMARY}

Small amounts of chondroitin sulfate added to serum increase the amount of euglobulin precipitated on dialysis. The amount of precipitate produced in euglobulin-free serum by addition of chondroitin sulfate has been studied as a func- tion of salt concentration, chondroitin sulfate added, $\mathrm{pH}$ and protein concentration. The difference in behavior of the albumin and pseudo globulin fractions of serum is very great and seems to be related to their different $\mathrm{pKi}$ values. Lysozyme added to dialyzed serum produces precipitates with chondroitin sulfate primarily related to its higher isoelectric point.

\section{REFERENCES}

1. Einbinder, J., and Schubert, M., Crystallization of calcium chondroitin sulfate. J. Biol. Chem., 1951, 191, 591.

2. Sandor, G., Sabetay, Y., and Vargues, R., Le système des globulines peu solubles du sérum. I. Etude de quelques relations entre les lipides et les protéides dans le sérum sanguin. Bull. Soc. chim. biol., 1953, 35, 273.

3. Jayle, M. F., Boussier, G., and Badin, J., Microdosage des protéines sériques par la méthode du biuret. Bull. Soc. chim. biol., 1951, 33, 881.

4. Alderton, G., Ward, W. H., and Fevold, H. L., Isolation of lysozyme from egg white. J. Biol. Chem., 1945, 157, 43.

5. Meyer, K., Palmer, J. W., and Smyth, E. M., On glycoproteins. V. Protein complexes of chondroitinsulfuric acid. J. Biol. Chem., 1937, 119, 501.

6. Badin, J., Jackson, C., and Schubert, M., Improved method for determination of plasma polysaccharides with tryptophan. Proc. Soc. Exper. Biol. \& Med., 1953, 84, 288.

7. Fromageot, C., Lysozyme. Bull. Soc. chim. biol., 1948, 30, No. 11-12 Suppl., 63.

8. Levine, A., and Schubert, M., Metachromasy of thiazine dyes produced by chondroitin sulfate. J. Am. Chem. Soc., 1952, 74, 91.

9. Altshuler, C. H., and Angevine, D. M., Acid mucopolysaccharide in degenerative disease of connective tissue, with special reference to serous inflammation. Am. J. Path., 1951, 27, 141. 